\title{
The Use of Collective Intelligence to Create Efficient Marketing Strategies
}

\author{
Adnane Derbani ${ }^{*}$, Ade Banani ${ }^{2}$ \\ ${ }^{1}$ PhD Student, Department of Management, Jenderal Soedirman University \\ ${ }^{2}$ Associate Professor, Department of Management, Jenderal Soedirman University \\ Jl. Profesor Boenyamin No.708 Purwokerto Utara Banyumas Central Java 53122 \\ *Email: adnane.derbani@mhs.unsoed.ac.id,
}

Naskah diterima 25 Juli 2020, Revisi 12 September 2020, Terbit 29 Oktober 2020

\begin{abstract}
Abstrak
DOI: doi.org/10.21107/pamator.v13i2.7326

Tidak diragukan lagi bahwa hampir semua perusahaan menyadari kebutuhan dan peran penting strategi pemasaran dalam perkembangan dan kemajuan bisnis apa pun. Namun, tantangannya masih bagaimana mengelaborasi dan membuat strategi pemasaran yang efektif. Tujuan dari penelitian ini adalah untuk menyelidiki dan menggambarkan bagaimana kita dapat membuat strategi pemasaran yang efisien dengan menggunakan pendekatan kecerdasan kolektif. Wawancara dilakukan dengan tim departemen pemasaran; ditambahkan ke peserta dari anggota departemen lain dan juga pelanggan dan pemangku kepentingan. melalui tiga langkah berbeda (sebelum, selama, dan setelah penggunaan pendekatan ini); untuk memberikan dan menemukan umpan balik dan hasil dari semua peserta melalui penerapan pendekatan kecerdasan kolektif. Berikut hasilnya; Ada konsensus dari partisipan studi penelitian ini yang menegaskan bahwa penggunaan konsep baru kecerdasan kolektif ini tidak hanya akan mentransformasikan desain lintasan elaborasi strategi pemasaran di masa depan tetapi juga masa depan pekerjaan.
\end{abstract}

Kata Kunci : bagian penjualan, kerja sama, performa kelompok

\begin{abstract}
There is no doubt that almost all companies recognized the necessity and the significant role of marketing strategies in the development and the progress of any business. However, the challenge still is how to elaborate and create effective marketing strategies. The purpose of this study is to investigate and illustrate how we could create efficient marketing strategies by using the collective intelligence approach. Interviews were conducted with marketing department teams; added to participants from other department members and also customers and stakeholders. Through three different steps (before, during, and after the use of this approach); in order to provide and discover the feedbacks and results of all participants through the implementation of the collective intelligence approach. Following the result; There is a consensus from the participants of this research study confirmed that the use of this new concept of collective intelligence will not only transform the design of the future trajectory of elaboration of marketing strategies but also the future of work.
\end{abstract}

Keywords: marketing department, collaborative work, group performance

\section{PENDAHULUAN}

When the human being is gathering together in order to think collectively is not a new operation on the opposite, this process existed since the beginning of humanity. The obstacle of making this interaction happen and being successful one; was and still the way how we practice it and that what makes the difference; the use of the approach of collective intelligence may affect deeply on its user's productivity if we apply it correctly.
To begin, let's define first what is the real meaning of Collective Intelligence? Collective intelligence refers to a group or a team's combined capacity and capability to perform a wide variety of tasks and to solve diverse problems (Prerna, 2017). In other words; the power of putting a number of brains together in order to come up with ideas that one person could not have come up with on his or her own in a creative and efficient way. 
On the other hand, when we talk about Marketing is an effective tool and strategy for increasing the sales of a product (Jager, 2007). It's obvious how Companies spend millions of dollars to implement successful strategies to make consumers talk about their products and create an effective relationship with them (Solomon et.al., 2008). However, one of the obstacles that faced by marketing teams during the phase of strategies elaborations; is the deceptive fact that said is only marketing department team who are supposed to focus on finding the right and the conveyable marketing strategies for any company; neglecting; and also underestimating the added value that can be offered by including and inviting other departments members from the same companies to be part of the process of creating marketing strategies.

The ambiguity behind the use of the approach of collective intelligence is considered one of the most challenge that the majority of companies if we don't say the totality they are faced by ignoring how they could have a robust advantage of using collective intelligence in the process of elaboration marketing strategies; whereas why losing this magic chance to have all the available brains internal or external from the enterprise to think together for the adaptable and effective marketing strategies that could offer to the companies opportunities for increasing productivity and profit and more precisely will allow all participants to find out and start having a sense of inclusion and belonging for the company.

This research faced a challenge of lack of literature relevant to; the fact of coming with a new way of doing marketing strategies represented difficulties but don't prevent it to find past research closer and related to our study; as (Kolter, 1976) confirmed about marketing strategies as being the grand design to achieve objectives. Furthermore (Chang and Campo Florence 1980) refer to marketing strategy as being crucial and central issues to the use of the marketing function; for (Jager, 2007) also Marketing has been an effective tool and strategy for increasing the sales of a product. Furthermore, for marketing strategies, companies look for segmentation of its consumers, provision of successful goods and services for each consumer segment and also employment of right promotional tools and pricing strategies to accomplish the company's objectives (Walker et.al., 2008). Marketers are expected to to create a marketing communication strategy that can attract customers' attention to the source pool where the next information about a product is obtained. So, that the form or appearance of the source pool that will be presented must really display things that can meet customer needs (Sugiyama and Andree, 2011). In the other hand, firms use different strategies to earn profit, such as, network relations (Dau, 2018) profit position and revenue from international sales. However, still are unexpecting challenges such as Changing the economic and social perspective is impacting marketing strategies of multinational firms (Naatu and Alon, 2019).

Human beings learn from their old experiences, get influenced by their social environment, and other; as an obstacle, traditional market models generally still concentrate on single individuals rather than taking social interactions into account (North et.al., 2010). In this context; we could easily notice the added value of the collective intelligence which refers to a group or a team's combined capacity and capability to perform a wide variety of tasks and solve diverse problems (Chikersal, 2017); and also, $\mathrm{Cl}$ defined as the ability of human groups to perform well on a variety of tasks (Giovanni, 2019). Collective Intelligence has been found to consistently predictive of the future performance of groups and teams. One of the studies that clearly showed the robust evidence of a collective intelligence factor in the performance of human groups that was led by Anita Williams Woolley, and her team in (2010 - Carnegie Mellon University); which results confirmed the power of $\mathrm{Cl}$ when we bring brains together in an organizing way that automatically increase performance. Furthermore, Collective intelligence has been manifested in boosting performance across a wide range of tasks, and the measure of $\mathrm{Cl}$ predicted future performance on more complex tasks such as those performed in software programming teams (Engel et.al., 2015; Yeonjeong, 2018).

As we have been mentioned above the lack of literature relevant to our study; was 
an incentive to examined this new approach and further effort to make this paper highlight and interpret how we could use Collective Intelligence to create efficient marketing strategies. The specific purpose of the current research is to illustrate a comprehensive approach to the conceptualization of the use of collective intelligence to create efficient marketing strategies.

\section{METHODOLOGY}

In order to gain a better insight into the possibilities for the application of Collective Intelligence to create efficient marketing strategies, we used semi-structured interviews based on open-ended questions divided in three major parts (before, during, and after the use of this approach). For this reason, we conducted interviews with the 28 Indonesian companies from a range of sectors such as (Banks - Communication Industry - IT - Distribution).

Firstly, Before the implementation of the Collective Intelligence approach, we desired to inform all the chosen participants which represented a mixture of job positions around 39 participants from marketing departments teams (Marketing Manager Product Manager); in addition to 45 participants from inside companies that are engaged in this study (Team leader, Engineer, Financial analyst, Technician); and also 12 participants from outside selected companies ( 7 Customers, 5 stakeholders) in order to inform them all about this study by explaining all the expected steps of this study; included the nature of all open-ended questions that will be asked. Interviews started since the beginning of this year 2020 and accomplished during the period of pandemic Covid19 for this reason many interviews moved from face to face interviews to online one using online call software; lasted between 20 and 30 minutes.

A list of open-ended questions was asked; for instance, what is the definition of collective intelligence for you? And also question like; what are the result and more precisely the extensive benefits after participating in this experience? List the most important values and output that you inferred through your participation during all the steps of implementation of the Collective intelligence approach? Furthermore, all interviews were recorded and transcribed in full. Thus, conclude from the analysis of their responses and feedbacks the possibility of the ability and the willingness for applying this approach of collective intelligence inside their companies.

\section{RESULTS AND DISCUSSION}

The interviews categorized by taking into consideration multiple aspects of the participants roles. The data set for this study consisted of the portions of the interviews relevant to the role of the participants; and more precisely to the three steps (mentioned above) of the implementation of Collective intelligence gathering. Each company selected to participate in this study; identified members of their teams and provided us with a list. Typically, participants were; Marketing Manager - Manager of different departments - Engineer - Financial analyst Technician. With the help of the marketing manager, we had the possibility to have also in our list participants from outside the company; such as Customers stakeholders. (Table1).

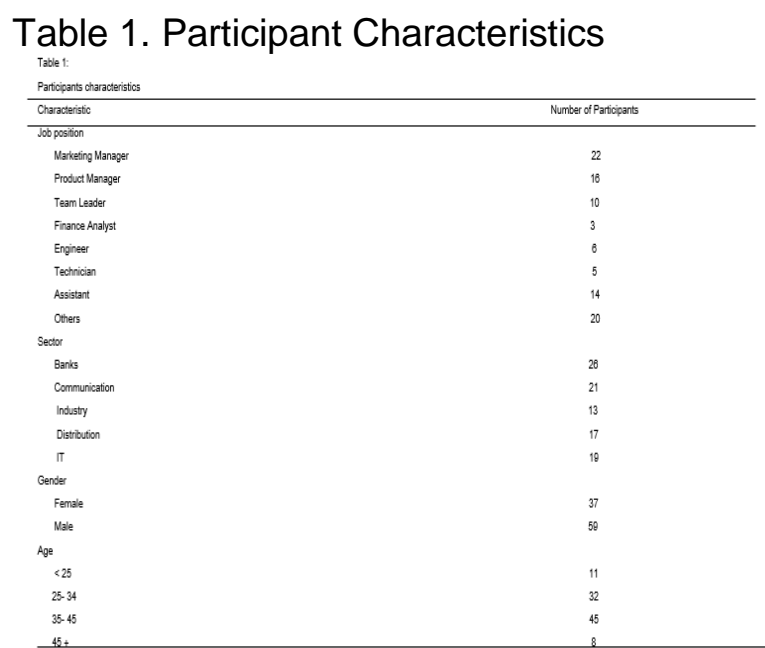

The results of this study highlight the value of the Collective Intelligence approach, and how it is important for giving the marketers the opportunity to create efficient marketing strategies. In addition, the use of this approach was again helpful in terms of increasing productivity and also to create strong relationships inside the company with different departments and also outside the company by creating and strengthening the 
relationship with customers and stakeholders.

The findings also provide additional empirical support for the notion of collective intelligence; this is an important finding not only for marketing departments but also for other teams and how it should be generalized as a new and creative way of work allowed to tackling challenges and developing new projects together. Numerous values were determined and shared by all participants; proved by their original answers; which is presented in the following part:

\section{Creativity}

The ability to produce or use original and unusual ideas this is creativity (Cambridge dictionary); and that what represented the use of this new approach of collective intelligence to all participants as an unusual experience; and more precisely a creative way that were glad to be part of, and experienced inside their companies. And that one of the reasons that encourage employees to start thinking out-of-the-box. "I never imagine that I will think differently this much and being in the same room with one of my customers thinking together about our next marketing strategy" (Marketing Manager, Bank sector)

\section{Inclusion}

The fact of making participants be part of this operation of creating efficient marketing strategies is the real meaning of collective intelligence that moment where many brains were gathering to think for the same purpose. But other advantages show up; one of them " Inclusion " when workers feel that the companies care about them and their knowledge in order to contribute to the good and the development of their companies by presenting suggestions and ideas. "My company asks for my help and it gives me a special feeling to be part of this exceptional experience and make it happen, and share and learn the maximum". Computer Technician (Distribution sector)

\section{Loyalty}

Nowadays, companies suffer on how to increase confidence of their customers and make them more loyal. However, it could be easier and less cheap when you surprise your customer and make them realize that you are not concerned only about their money but also about their knowledge to develop your products and services to make it better for them. "When the company of one of the products or services that you use asked for your help to share with them your ideas on how they could develop marketing strategies; it is really a special feeling for a customer like me; it's really an unique feeling to share my opinion and my knowledge" (Customer)

\section{Cooperation and Solidarity}

Cooperation and solidarity among workers in the same company, it is considered as a decisive factor to achieve professional success and increase performance. This study clearly showed how we could realize this aspect inside any enterprise by using the collective intelligence approach. "By being inviting in this experience, I was inspired to think about using the same approach of collective intelligence with my team. Because I really discover how it helps any team to increase cooperation and solidarity between their members by involved everyone" (Financial Analyst, Industrial sector).

These findings raise many additional questions. For example, could the use of collective intelligence not only help to create efficient marketing strategies but also to increase productivity inside companies? Could the use of collective intelligence not only help to create efficient marketing strategies but also to increase performance inside companies? Absolutely, yes for both questions. Related to the majority of participants; the fact of combining different departments to face challenges and create a variety of projects together; it will not only increase productivity and performance inside any company but also other strong values such as creativity; inclusion and loyalty.

The first part was also characterized by the organization of session of information to the participants that belong to the same companies but from different departments, about 84 participants with various position (such as Manager, Engineer, Financial analyst, Technician) added to 12 participants from outside the companies (7 Customers, 5 stakeholders.) to inform them all about 
collective intelligence approach and all the supposed steps of the process.

The second part was reserved for the application of this new approach of collective intelligence with marketing departments that invited all participants. The last part was dedicated for generating the result and all feedbacks by using again the open-ended questions interview addressed to all 96 participants from inside and outside the companies. Prior to collecting the data, we took several steps to address ethical concerns and to ensure participants commitment to the study. First, Marketing managers; who will be participating in this study received a description of our research in order to describe all the steps that we will follow, also we shared with them all the goals expected and assuring to them confidentiality will be respected.

Next, we encouraged all participants from inside and outside companies to ask us questions and request clarifications. hence, at the beginning of each interview, we presented all instructions accompanying included a brief explanation of the study's purpose and steps in order to assure presumably fostered all participants cooperation.

Moreover, these findings are encouraging for research on collective intelligence approach, even there are also some limitations inherent in our study. First, using interviews as a methodology in this study was representing a limitation to test the collective intelligence approach from different perspectives; without forgetting the confidentiality asked by companies that participated in this study. Whit this reason of confidentiality, we faced again a limitation in order to have the chance to measure the impact of marketing strategies. Second potential limitation, was identified during the interviews; we discovered at the level of implementation of the approach of collective intelligence; regarding managers; that they had a lack of skills of facilitation which represented a kind of barriers to make the gathering of participants from different departments having a flexible meeting rather than a complex one.

The participants for our study faced a variety of obstacles; through all the steps of using the collective Intelligence, approach (before, during, and after the use of this approach); illustrated on the following Figure 1:

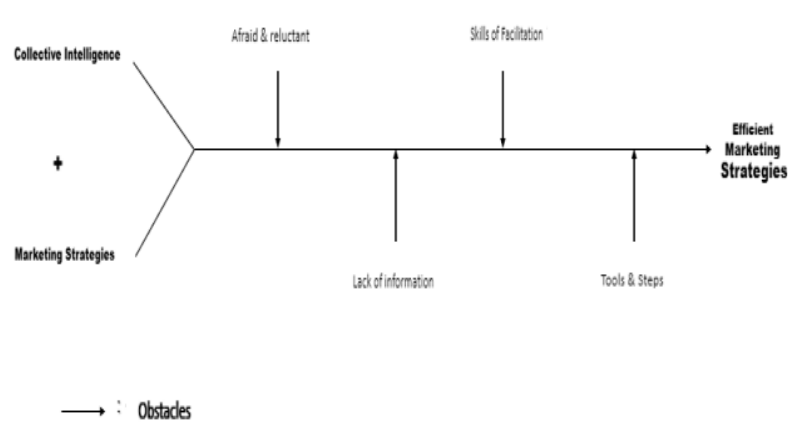

Figure 1. List of Obstacles Faced the Use Of The Collective Intelligence Approach In Order to Create Efficient Marketing Strategies

As a result, we had plenty of interesting questions for future research; on one hand, how we could develop a study about the skills of facilitation that enables all the meetings not only for those for elaborating marketing strategies but also for all others kind of meetings to make it succeed. On the other hand, we found out the misconception between the term of intelligence IQ, and the term presented in our study Collective intelligence when many participants in our research study had difficulty to make difference between both terms. As a result, many studies should be conducted in order to demystify the ambiguity about the collective intelligence signification and approach.

\section{CONCLUSION}

Change is awesome, but to make it happen that is the real challenge for any new concept or idea; we can be really surprised what it is possible to be achieved through a collective intelligence approach and how it will shape the future trajectory of a new method of elaboration marketing strategies.

Following the result; There is a consensus from the participants of this research study confirmed that the use of this new concept of Collective Intelligence was an unusual experience for them and it makes them think differently and more precisely think together to combine efforts; 
skills and ideas of all workers without any sensitivities for the good benefit to everyone. As a final result, it will transform not only the design of the future trajectory of elaboration of marketing strategies but also the future of work.

Today, more than ever, marketers must have a multi-level vision for elaborating marketing strategies that are based on innovation and creativity and more precisely includes collective intelligence approach as an axis in order to get out of the monotony of limited-horizon strategies into strategies more participative; collaborative and inclusive that lead to efficient results.

\section{REFERENCES}

Aggarwal, I., Woolley, A.W. 2018. Team Creativity, Cognition, and Cognitive Style Diversity. Journal Management Science. 1-14 pp.

Anita, W., Alex, P., Christopher, F.C \& Nada, $\mathrm{H}$. 2010. Evidence of a Collective Intelligence Factor in the Performance of Human Groups, Science.

Anita, W. A., Thomas, W. 2015. Collective Intelligence and Group Performance. Curr. Dir. Psychol Sage Journals. Sci. Vol 24 (6). 420-424 pp.

Ataman, M. B., Van Heerde, H. J., \& Mela, C. F. 2010. The Long-Term Effect of Marketing Strategy on Brand Sales. Journal of Marketing Research. Vol 47(5), 866-882 pp.

Atuahene-Gima, K., \& Murray, J. Y. 2004. Antecedents and Outcomes of Marketing Strategy Comprehensiveness. Journal of Marketing. Vol 68(4). 33-46 pp.

Benson S. 2002. Want a Happy Customer? Coordinate Sales and Marketing Harvard, Business School Working Knowledge.

Buzzell, R. D., \& Gale, B. T. 1987. The PIMS Principles: Linking Strategy to Performance. New York: The Free Press.

Chang, J.W., Chow, R.C., \& Woolley, A.W. 2017. Effects of Inter-Group Status on The Pursuit of Intra-Group Status. Organizational Behavior and Human Decision Processes. Vol 139. 1$17 \mathrm{pp}$.
Carola, G. Maike, B. 2011. A Way to More Effective Marketing Strategies: Analyzing Dimensionality of Cognitive Structures Quantitatively. Sage journals.

Chikersal, P. Maria, T. Young JK. 2017. Deep Structures of Collaboration: Physiological Correlates of Collective Intelligence and Group Satisfaction. Proceedings of the 20th ACM Conference on Computer-Supported Cooperative Work and Social Computing- CSCW 2017.

Dau, L.A. 2018. Contextualizing International Learning: The Moderating Effects of Mode of Entry and Subsidiary Networks on The Relationship Between Reforms And Profitability. Journal of World Business. Vol. 53 (3). 403-414 pp.

Engel, D., Woolley, A. W., Aggarwal, I., Chabris, C. F., Malone, T. W. 2015. Collective intelligence in online collaboration emerges in different contexts and cultures. In Proceedings of the 33rd Annual ACM Conference on Human Factors in Computing Systems (CHI '15) (pp. 3769-3778).

Goldstone, R \& Janssen, M. 2005. Computational Models of Collective Behavior. Trends in Cognitive Science. Vol 9. 424-430 pp.

Jager, W. Delre, S. Janssen, M (2007). Targeting and Timing Promotional Activities: An Agent-Based Model for the Takeoff of New Products. Journal of Business Research. Vol 60 (8). 826- 835 pp.

McGrath, J.E. 1984. Groups: Interaction and Performance. Prentice-Hall, Englewood Cliffs, NJ. 287 pages.

John, M., Orville W., J.C Larreche. 2004. Marketing Management: A Strategic Decision-Making Approach. McGrawHill/Irwin; 5-edition.

Jordan, R. Audrey, G. Paula, D. 2011. The Marketing Concept in The 21st Century: A Review of How Marketing Has Been Defined Since The 1960s. The Marketing Review.

Hackman, J.R 2002. Leading Teams: Setting the Stage for Great 
Performances. Harvard Business Press, Boston. 312 pages.

Kim, Y. J., Engel, D., Woolley, A., Lin, J., McArthur, N., \& Malone, T. 2017. What Makes A Strong Team? Using Collective Intelligence To Predict Performance Of Teams In League Of Legends. Proceedings of the 20th ACM Conference on Computer-Supported Cooperative Work and Social Computing (CSCW 2017).

Malone, T.W., Laubacher, R., Dellarocas, C., 2010. The Collective Intelligence Genome. MIT Sloan Manag. Rev. 51 (3), 21.

Morgan, N. A., Whitler, K. A., Feng, H., \& Chari, S. 2019. Research in Marketing Strategy. Journal of the Academy of Marketing Science. Vol 47(1). 4-29 pp.

Palmatier, R. W., \& Sridhar, S. 2017. Marketing Strategy: Based on First Principles and Data Analytics. Macmillan International Higher Education.

Rajan, V. 2010. Strategic Marketing and Marketing Strategy: Domain, Definition, Fundamental Issues and Foundational Premises. Journal of the Academy of Marketing Science. Vol 38(2). 119-140 $\mathrm{pp}$.
Reibstein, D. J., Day, G., \& Wind, J. Guest. 2009. Is Marketing Losing Its Way?. Journal of Marketing. Vol 73. 1-3 pp.

Slater, S. F., Hult, G. T. M., \& Olson, E. M. 2010. Factors Influencing The Relative Importance of Marketing Strategy Creativity and Marketing Strategy Implementation Effectiveness. Industrial Marketing Management. Vol 39 (4). 551559 pp.

Solomon, M., Greg, W. 2008. Marketing: Real People, Real Choices. Prentice Hall, New Jersey. Pearson; 9edition.

Tilmann, B. 2010. Marketing Intelligent Systems Using Soft Computing Collective Intelligence in Marketing Chapter. Springer, Berlin, Heidelberg, pp 131-154.

Walker, O. John, M. 2008. Marketing Strategy: A Decision Focused Approach, MacGraw-Hill, New York. 8th Edition- 364 pages.

Woolley, A.W., Fuchs, E.,. 2011. Collective Intelligence in The Organization of Science. Organ. Sci. 22 (5), 1359-1367.

Woolley, A.W. 2011. Responses to Adversarial Situations The Implications for Collective Intelligence. Journal of Organizational Behavior. Vol 32. 978-983 pp. 